\title{
Shifting communication practices in Japanese courtrooms
}

Edition 2, 2020

Dr Ikuko Nakane

DOI: 10.37839/MAR2652-550X2.13

Japanese criminal trials have shifted towards a more adversarial orientation following major law reform implemented over the past 20 years. Lawyers have had to adapt to the new context of professional communication with lay judges, who sit with professional judges in some trials rather than taking the role of citizen juries. For the defence and prosecution, a need to 'win the battle' with convincing courtroom performance and communication strategies have posed challenges, while judges still have the power to take an investigative stance to pursue the truth. This article explores how the shift towards an adversarial orientation manifests itself in the courtroom, and discusses the dilemma over the need for courtroom performance focused on spoken language and the trust in written communication that traditionally dominated the criminal justice process.

\section{The 'hybrid' Japanese justice system}

Japan looked towards France and Germany for its legal system during its transition from the feudal era to the Meiji restoration in the late $19^{\text {th }}$ century. Japan adopted essentially an inquisitorial, or continental legal system, which primarily assigned the court the role of investigation and pursuit of the 'truth' with the state investigators. After Japan's defeat in WWII, some elements of adversarial justice processes were introduced to the Japanese justice system, following the common law system of the USA. Under this system, the accused, mostly represented by defence attorneys, appear in court to give evidence and they are presumed innocent unless the 
evidence proves their guilt beyond reasonable doubt.

The Japanese term tōjisha shugi, which literally means 'the principle of parties' or 'party-focused principle', is often translated as 'adversarial system'. Under the töjisha shugi system the prosecution has the burden of proof, evidence and witnesses are usually presented by both parties, and the judge presides over the court proceedings as a 'neutral' referee. Witnesses are usually examined by both parties, and in contested cases, witnesses could be put under the intense pressure of relentless questioning from counsel.

This kind of strategic use of rhetoric and questioning by the counsel characterises the 'adversarial' aspect of Japanese criminal trials. Scholars who have studied language of the courtroom in common law adversarial systems often characterise the court as a battleground for competing stories: what matters is which side can present a more convincing story to the jury, weaving the evidence into it.

A feature of the inquisitorial system which has been retained in Japan is that judges usually ask 'supplementary questions' of the witness after the counsel's examination, which may go beyond clarifications and aim to discover relevant details of the crime or circumstances which the counsel have not addressed. This might come as a surprise to people who are familiar with the common law adversarial system such as that of Australia, where judges do not pursue the 'truth-finding' path through their own questioning in court. For the counsel, this investigative stance may at times 'spoil' their adversarial approaches to the courtroom proceedings.

Traditionally, continental law jurisdictions with their inquisitorial orientation to justice relied more on written documents than in common law jurisdictions such as the US or Australia where verbal communication is more prominent in trials. Although witnesses are examined directly and counsel read out their arguments at the end of each trial, the Japanese criminal justice procedure has been criticised because of its over-reliance on chōsho or suspect/witness statements based on confessions taken by police or prosecution. In fact, there have been some acquittals 
because of false confessions presented in the form of chōsho in recent years, such as the case of Sugaya Toshikazu, who was acquitted after spending over 17 years in custody. Sugaya was accused of the murder of a young girl that took place in 1990 after providing confessions pre-trial, but then he denied the allegation at trial. After a retrial with new DNA evidence and tape-recording of his interviews he was exonerated. But this over-reliance on written police statements as evidence has changed in recent years, mainly due to the judicial reform that started in 1999.

\section{A shift towards the courtroom as a battleground for competing narratives}

As part of the large-scale justice reform following the Justice System Reform Council (1999-2001), citizen participation in Japan's justice process was implemented through the saiban-in system in 2009. This brought back participation of citizens in trials (Japan had jury trials only for a short period of time (1928-1943)). These reforms followed international pressure to address human rights issues in Japan's criminal justice system, but also a perceived need for modernising the system. Thus, along with the saiban-in system, an array of changes such as graduate-level law schools and the establishment of the Japan Legal Support Centre was introduced.

Saiban-in trials are held for serious criminal cases such as homicide, robbery causing injury and kidnapping. Six lay judges are selected from the electoral roll to join three professional judges. The lay judges participate in deciding the verdict and the sentence. While the proportion of saiban-in trials appear to be small $(1.6 \%$ of the total number of defendants in new cases in district courts in 2018), the introduction of citizen participation in the legal system has drawn much media attention. Furthermore, the courts' extensive campaign to disseminate information on saibanin trials to citizens brought the justice system and its issues to the fore in public discourse.

There was a shift in communication practices in Japanese courts after the 
introduction of the saiban-in system in 2009. One key feature of adversarial trials is competing narratives, where communication strategies serve as powerful tools. More convincing narratives require effective questioning strategies in witness examination. Questions are carefully sequenced to reveal inconsistencies in the account of witnesses or the defendant. Counsel will jump in to object to leading questions asked in examination-in-chief, or to ask the other party to withdraw or correct inaccurate representations of earlier courtroom testimony. When questioning their own witnesses, the counsel controls the answers by interrupting them if they start to go off topic and risk giving damaging information which could be picked up by the opposing counsel.

In one saiban-in trial I observed in my fieldwork, leading questions were sometimes asked that elicited important information. The defendant was accused of robbery resulting in injury. After probing questions regarding the location of the defendant's arm in relation to the victim's neck, which revealed some inconsistencies in the defendant's evidence, the prosecutor asked 'Wasn't the victim's neck restricted/clenched/tightly locked in?' (Quotes hereafter have been translated from Japanese by the author.) Following the defendant's agreement, another question was asked: 'Does that mean you acted in a way in which you strangled her?', to which the defendant answered 'Yes'. Further probing took place regarding the location of the arm which the defendant claimed was under the victim's body when they fell over together, and the prosecutor asked 'Didn't you just try to pull your arm out when you saw the motorbike while you were strangling the victim?'. Negative questions such as these have coercive power and suggest doubts about the veracity of the defendant's claim. The defendant denied this, resisting the pressure to accept the prosecution's narrative.

The defence used detailed questioning to cast doubt that any robbery had occurred because the victim said the defendant would not take her purse even when she raised it a few times to draw the defendant's attention. When the defence asked whether 'the defendant noticed the purse', she responded '[...] he would not take it even though I showed it to him many times'. Later, when the defence mentioned that 
the victim 'strongly appealed' to the defendant with the purse, the prosecutor cut in to say 'She did not say 'strongly'. The two parties' confrontational exchange illustrates the significance given to the wording of spoken evidence in court. This is an example of a competitive nature of interaction in saiban-in trials which is more likely to be found in adversarial trials than in inquisitorial trials. This type of interaction did take place before the introduction of the new system, especially in highly-contested cases, but it has become more common in recent years. The amount of training in courtroom advocacy skills and lawyers' perceptions of the changes due to the saiban-in system reflect the heightened level of awareness and application of adversarial courtroom communication skills. Before the saiban-in system, professional judges would more often depend on evidential documents (including police statements) outside the courtroom, but in saiban-in trials that is not possible.

Another feature of the adversarial orientation is the use of semantic strategies to project their preferred images of defendants, witnesses or victims. For example, in one saiban-in trial I observed in Japan, the defendant, who was accused of bodily injury resulting in death, was described by the prosecutors as a 'king' (oosama) and the victim as a 'servant' (geboku/kerai/meshitukai); whereas the defence depicted their relationship as 'friends' (tomodachi). The prosecution intended to project an image of the defendant as a violent bully towards the witness and the deceased victim; while the defence portrayed him as a socially and morally acceptable character. One prosecution witness responded to the prosecutor's question about the relationship between the victim and the defendant: 'Well it seemed like the boss and the henchmen or servant type of relationship.' Another witness claimed to have been treated like a 'servant', which was also mentioned in the closing argument in referring to the victim whom the defendant 'used like a servant'.

These features of courtroom discourse in the saiban-in system are some indications that there is an increasing focus on orality in Japanese trials. The performance skills required are not limited to questioning skills and constructing a strong narrative, but also include effective use of other semiotic resources such as the use of non-verbal communication or visual aids. The Bar Association training involves guidance in 
postures, eye contact, where to stand, going 'paperless' and so on to equip their members with effective non-verbal communication strategies, often modelling their approaches to advocacy on the National Institute for Trial Advocacy (NITA) in the US.

In a number of saiban-in trials I observed, the defence counsel would move away from their seats and come closer to the bench to face the judges for their closing argument. This practice had rarely been seen in pre-saiban-in trials, but has been encouraged by organisers of some branches of the Federation of Bar Associations, following the highly performance-oriented US style advocacy practice. Interestingly, however, the prosecutors always presented their opening statements and closing arguments from behind their desks. Considering that the burden of proof rests with the prosecution, this is rather paradoxical, but the power that prosecutors have in Japan may mean that they may not need to deploy another communicative strategy for extra appeal to the judges.

\section{Tension between spoken and written modes of communication}

While we observe an increasing focus on courtroom performance and communication skills in the Japanese criminal justice system, it is important to recognise that, despite the publicity, saiban-in trials only take up a small proportion of criminal trials in Japan. A majority of cases are tried by professional judges, who still rely on written records of police and prosecution interviews.

Nevertheless, the introduction of saiban-in trials has had a ripple-effect on professional judge-only trials, and a move towards having more direct examination of witnesses appears to be taking place across the board. This in turn is a move away from written statements (chōsho) taken by police or prosecution interviews as evidence. Judges traditionally depended on and read these outside the courtroom, which still happens in non-saiban-in cases to a certain extent. But audio-visual 
recording of police and prosecution interviews has become mandatory for cases that are to be tried by lay judges since 2016, and the shift towards orality is also gradually appearing in the investigative phases of criminal cases.

This is not to say, however, the increasing focus on spoken communication and nonverbal communication in the courtroom is entirely positive. Some lawyers express concern for over-reliance on courtroom performance in the justice process at the cost of fully and accurately presenting evidence. There is a certain level of skepticism towards the element of performance, whereby going 'paperless' and ensuring eye-contact with the judges may be viewed as 'ridiculous' or 'too obvious' due to their awkward or over-theatrical manner, especially if the lawyer is inexperienced. One way this dilemma is commonly resolved in saiban-in trials is by utilising visual aids such as PowerPoint and handouts to guide lay judges through the evidence and legal points in opening and closing arguments.

For example, in closing arguments in one saiban-in trial, both counsel had distributed a handout called a 'memo', which they went through by referring to the key 'points', often indicated by numbers, as in 'Please have a look at Memo 1, where it says contested issues. ... I'll now explain. Please have a look at point 1,...' The problem with this mixed-mode approach is that it is not totally compatible with the 'theatrical' or 'performance' element of the adversarial courtroom practice. Explicit requests to pay attention to specific sections in the handout prevent the judges from having an eye contact with the lawyer as the judges' attention is then drawn to the handout; thereby diminishing the role of persuasive non-verbal communication. There are of course experienced and highly respected defence attorneys with effective courtroom communication skills and those skills are valued in the context of Japanese criminal justice system, especially given the power of prosecutors; the fact that the judges' role is mostly confined to sentencing; and that the rate of not guilty judgements is less than $1 \%$.

However, using written communication as an aid to oral communication can benefit the legal process, especially with regard to lay participants' comprehension of the 
courtroom proceedings. Lay judge trials are generally held over consecutive days, which may cause fatigue and comprehension issues. Hearing lengthy final arguments after days of proceedings may affect lay judges' ability to take in all the key points and details presented for their decision-making. In fact, experts in law and language of the law have long discussed issues concerning lay comprehension of legal language and recommendations have been made to provide a written version of jury instructions or other resources to support comprehension of courtroom communication. Japan's Lay Assessor Act (Saiban-in Hō) (Article 51) obliges judges and counsel to 'make the hearing expeditious and comprehensible' for lay judges.

The combination of communicative modes in lay judge courts in Japan may have something to offer for lay-professional communication in other jurisdictions where oral communication is given much more weight than in the Japanese justice system, although current legal constraints on the proceedings are likely to exclude supplementary tools such as summary handouts.

\section{The impact of shifting power dynamics in the legal process}

The big questions are how the changing communication practices contribute to the delivery of justice, and how Japan's legal system will embrace challenges and possibilities of communication following large-scale reform.

As mentioned above, Japan is known for its consistently high conviction rate, but unlike the US and other common law jurisdictions, defendants who admit guilt will still go through a trial. The defence might contest the nature of the offence or typically argue for leniency, which bring about a type of 'battle' in the courtroom somewhat different from that we find in common law trials. The saiban-in system has not had significant impact on the conviction rate, and in some cases, penalties were higher than the pre-saiban-in system period. Furthermore, pre-trial procedures still favour the prosecution, and judges still tend to be more cooperative with 
prosecutors, as has been often discussed by legal studies scholars.

Nevertheless, although defence attorneys do not have the institutional support that prosecutors enjoy, as more and more defence attorneys are trained in courtroom communication strategies, the defence side may see some benefit from the new system.

We also should not overlook the impact of the change on Japanese society. Saiban-in cases have been widely reported in the media, and due to the possibility of participation in trials as lay judges, public awareness concerning criminal justice processes has risen. There are more watchful eyes on the justice process and communication in the legal system.

Image: Supreme Court of Japan: Image credit: 江戸村のとくぞう/WikiCommons 